\title{
Manichaean Women in Augustine's Life and Works
}

\author{
Johannes van Oort \\ Radboud University Nijmegen \\ University of Pretoria \\ email: j.vanoort@planet.nl
}

\begin{abstract}
The study of women in Manichaeism is still in its infancy. The present article aims to contribute to this promising field of research by concentrating on the writings of the former Manichaean Augustine (354-430). A considerable number of data emerge from his works, which elucidate the presence and role of Manichaean women in Roman North Africa. It turns out that, at quite different stages of his life, Augustine came into contact with female Manichaeans and described their significance very differently.
\end{abstract}

\section{Keywords}

women - Manichaeism - Augustine of Hippo - early Christianity - Roman North Africa

\section{Introduction}

The past years saw the publication of the first studies on women in Manichaeism. ${ }^{1}$ Until recently, none of them focused on the textual data

* I would like to acknowledge Jason BeDuhn, Jan den Boeft, Madeleine Scopello and Yolande Steenkamp for their attentive reading and assistance. This article was completed with the help of the National Research Foundation (NRF) in South Africa.

1 J.K. Coyle, 'Prolegomena to a Study of Women in Manichaeism' (2001), repr. in Coyle, Manichaeism and Its Legacy, Leiden-Boston 2009, 141-154; idem, 'Women and Manichaeism's Mission to the Roman World' (2006), repr. in Coyle, Manichaeism and Its Legacy, 187-205 (cf. idem, 'Mary Magdalene in Manichaeism?' (1991), in Coyle, Manichaeism and Its Legacy, 155-172; and idem, 'Rethinking the "Mary's" of Manichaeism' (2005) in Coyle, Manichaeism and Its Legacy, 173-186); M. Scopello, 'Femmes et propaganda dans le manichéisme', Connaissance des Pères de l'Église nr. 83 (2001) 35-44; eadem, 'Les passionarias du manichéisme: le rôle des 
provided by what is conceivably the most rewarding source, namely the writings of Augustine. ${ }^{2}$ Being both a former Manichaean and a most prolific writer, one may suppose that Augustine could provide many details which may help to enrich this still pristine field of study. Indeed, on close inspection of his œuvre, a considerable number of interesting data on Manichaean women has surfaced.

The present study sets forth an overview of these mostly unexplored data, providing a detailed discussion against the background of information on certain persons that could be detected. As far as possible, I present all persons and their data in chronological order. At the end of the paper, I formulate some preliminary conclusions and suggest some areas for further investigation.

\section{Mother of unknown bishop, ca. 325, Roman Africa (source: conf. 3,21)}

The first person to be listed is the mother of the bishop to whom Monnica once communicated her sorrows about her son. She is mentioned at the end of conf. $3 \cdot{ }^{3}$ Somewhere in Roman Africa, in all probability either in Carthage or

femmes dans la propaganda', Religion et histoires nr. 3 (juillet-août 2005) 44-47 (cf. eadem, 'Julie, manichéenne d'Antioche', Antiquité tardive 5 (1997) 187-209, repr. in Scopello, Femme, Gnose et Manichéisme, Leiden-Boston 2005, 237-291 and eadem, 'Bassa la Lydienne', in Scopello, Femme, Gnose et Manichéisme, 293-315); M. Franzmann, 'Tehat the Weaver: Women's Experience in Manichaeism in 4th Century Roman Kellis', Australian Religion Studies Review 20 (2007) 17-26 (cf. eadem, 'The Treasure of the Manichaean Spiritual Life', in 'In Search of Truth': Augustine, Manichaeism and Other Gnosticism, Leiden-Boston 2011, 235-243; eadem, 'Augustine and Manichaean Almsgiving: Understanding a Universal Religion with Exclusivist Practice', in J. van Oort (ed.), Augustine and Manichaean Christianity, Leiden-Boston 2013, 37-49). The unpublished 2012 Augsburg dissertation of Jessica Kristionat entitled Zwischen Selbstverständlichkeit und Schweigen: die Rolle der Frau im frühen Manichäismus has up to now been unavailable to me. Apart from these more or less specific studies, there are scattered remarks on Manichaean women in general works and other studies on Manichaeism; when relevant to the present scope, they will be mentioned in due course.

2 Despite its broad title, the recently published paper of N.J. Baker-Brian, 'Women in Augustine's Anti-Manichaean Writings: Rumour, Rhetoric, and Ritual', $S P$ 70, Leuven 2013, 499-520, mainly has another focus (sc. the role of rumour) and, unfortunately, is marred by several misreadings of the Latin text (those relevant in this context will be discussed below). The same focus (and misreadings) in N. Baker-Brian, 'Between Testimony and Rumour: Strategies of Invective in Augustine's De moribus manichaeorum', in: Alberto J. Quiroga Puertas (ed.), The Purpose of Rhetoric in Late Antiquity. From Performance to Exegesis, Tübingen 2013, 31-53.

3 Conf. 3,21: 'Et dedisti alterum responsum interim, quod recolo. nam et multa praetereo, propter quod propero ad ea quae me magis urguent confiteri tibi, et multa non memini. dedisti ergo alterum per sacerdotem tuum, quendam episcopum nutritum in ecclesia et exercitatum 
in Augustine's home town of Thagaste, Monnica approached a certain bishop (quendam episcopum). ${ }^{4} \mathrm{He}$ tells her to be not too anxious about her son's enthusiasm for the newly discovered Manichaean belief, but to let him there (sine illum ibi), i.e. in the heresy (haeresis) of the Manichaeans. He then motivates his advice with the story that 'he himself, as a small boy (parvulum), had been handed over (datum fuisse) to the Manichaeans by his misguided mother and had not only read nearly all their books, but even copied them (scriptitasse libros eorum)'. And, 'although he had no one disputing with him and providing a refutation, it had become clear to him that that sect (secta) was something he should flee from. So he had fled'.

A number of typical facts in this narrative may be stressed. A parvulus, i.e. a (very) small boy, had been handed over (datum fuisse) by his mother.

in libris tuis. quem cum illa femina rogasset, ut dignaretur mecum conloqui, et refellere errores meos, et dedocere me mala ac docere bona-faciebat enim hoc, quos forte idoneos invenisset-noluit ille prudenter sane, quantum sensi postea. respondit enim me adhuc esse indocilem, et quod inflatus essem novitate haeresis illius, et nonnullis quaestiunculis iam multos inperitos exagitassem, sicut illa indicaverat ei. sed inquit sine illum ibi. tantum roga pro eo dominum: ipse legendo reperiet, quis ille sit error et quanta inpietas. Simul etiam narravit, se quoque parvulum a seducta matre sua datum fuisse Manichaeis, et omnes paene non legisse tantum verum etiam scriptitasse libros eorum, sibique adparuisse nullo contra disputante et convincente, quam esset illa secta fugienda: itaque fugisse. quae cum ille dixisset, atque illa nollet adquiescere, sed instaret magis deprecando et ubertim flendo, ut me videret et mecum dissereret, ille iam substomachans: vade inquit a me; ita vivas, fieri non potest, ut filius istarum lacrimarum pereat. quod illa ita se accepisse inter conloquia sua mecum saepe recordabatur, ac si de caelo sonuisset'.

4 P. Courcelle, Recherches sur les Confessions de saint Augustin, Paris $1950\left(1968^{2}\right), 68$ speaks of 'un évêque catholique de passage' and sets the story during the time of A. teaching grammar in Thagaste. This interim period, however, is discussed in conf. 4,4-12. The best option seems to be the time of A.'s rhetoric study in Carthage, although one may concede some chronological inconsistency in A.'s account. The 'interim' ('meanwhile'; 'meantime'; 'for the time being') at the beginning of the story of 3,21 is rather vague and seems to refer to the 'almost nine years' mentioned in 3,20.- J.J. O'Donnell, Confessions, II, 201, makes mention of some conjectures regarding a certain Antigonus of Madauros as being perhaps the unknown bishop, but this is pure speculation and, moreover, runs the risk of putting us on the wrong track: A.'s time in Madauros has nothing to do with his time as a Manichaean. Also, O'Donnell's further quote of Frend, Donatist Church, 236: 'Apart from Augustine himself and Alypius, successive bishops of Constantine, Profuturus and Fortunatus, were ex-Manichees', is beside the point: both Profuturus and Fortunatus (in older studies often considered to be former members of A.'s monasterium in Hippo) were in office only many years later. Cf. PAC s.v. Profvtvrvs (...391?-394/395-397/401) and Fortvnatvs 5 ( . 397/401-411-425? ...). 
Child oblation was not only a medieval phenomenon, ${ }^{5}$ but already occurred in ancient Israel and later Judaism. ${ }^{6}$ It also occurred in North African Manichaeism, ${ }^{7}$ probably in imitation of Mani himself who-according to the famed report of Ibn an-Nadìm in his Fihrist - was handed over to a group of baptists (al-Mughtasila) in Southern Babylonia in his early life. A close reading of the an-Nadim report reveals that in this oblation his mother had a certain share as well. Concerning Mays or Marmaryam, the wife of Mani's father Futtuq who had just joined the Mughtasila, it runs in Bayard Dodge's translation of an-Nadimm's Arabic text: 'They [i.e. the Mughtasilah] belonged to the cult which Futtuq was ordered to join when his wife was pregnant with Mānī. When she gave birth to him, they asserted that she had seen lovely dreams about him and that, upon awakening, she had beheld a vision, as though someone had taken hold of him and mounted with him to the sky. He brought him back, but perhaps he was on high for a day or two before he returned. Then his father sent and brought him to the place where he was, so that he was reared with him, in accordance with his cult'. ${ }^{8}$ From the Cologne Mani Codex it rather recently became clear that this happened when Mani was four ${ }^{9}$ and that the baptists were (a group of ) Elkesaites.

Augustine tells that the mother of the African bishop made her oblation when he was a parvulus. There is every reason to conclude that the mother of a devout Manichaean auditor or catechumen. According to the Kephalaia, one of the 'three great works' or 'alms' of the Manichaean catechumen was child oblation..$^{10}$ In addition, the boy is told to have stayed with the Manichaeans

5 M. de Jong, In Samuel's Image: Child Oblation in the Early Medieval West, Leiden-New YorkCologne 1996.

6 E.g. 1 Sam 1; Josephus, $B J$ 2,8,2 (120) on the Essenes: 'Marriage they disdain, but they adopt other men's children, while yet pliable and docile, and regard them as their kin and mould them in accordance with their own principles' (transl. H.St.J. Thackeray, Josephus, The Jewish War, Books I-III, Cambridge, Mass. 1967, 369).

7 As well as among the Manichaeans in Italy, according to mor. 2,54. Here the children who are obliged to eat the remnants of the sacred meal are indicated as being pueri and those children who died consequently (Courcelle, Recherches, 77 erroneously speaks of only ''un des enfants') as parvuli.

8 B. Dodge (ed., transl.), The Fihrist of al-Nadim. A Tenth-Century Survey of Muslim Culture, II, New York-London 1970, 774 .

$9 \quad$ CMC 11,1f. Cf. e.g. A. Henrichs \& L. Koenen, Der Kölner Mani-Kodex, Opladen 1988, 6f.; iidem, 'Der Kölner Mani-Kodex', ZPE 19 (1975) 13.

10 Kephalaia Lxxx, in: [H.J. Polotksy—A. Böhlig, eds.], Kephalaia, Band I, 1. Hälfte (Lieferung 1-10), Stuttgart 1940, 193, 4-11, in Gardner's translation (I. Gardner, The Kephalaia of the Teacher. The Edited Coptic Manichaean Texts in Translation and Commentary, Leiden- 
and 'had not only read nearly all their books but had even copied them (scriptitasse libros eorum)'. Since the recent discovery of the Kellis texts we know how in Manichaean circles youngsters were employed in the copying of books." Remarkable as well is Augustine's speaking of 'nearly all their books' (omnes paene... libros eorum). Was there a certain corpus of Manichaean books in Latin? From several testimonies in his œuvre, we know that Augustine was very well informed about the contents of Mani's books ${ }^{12}$ and even expressed his opinion on the quality of their Latin translations. ${ }^{13}$ Both from the story in conf. 3 and the just quoted remark on their translations one may infer that, already since some decades before Monnica's encounter with the unknown bishop, Latin Manichaean books were in circulation in Roman North Africa, i.e. at least from the middle of the fourth century onwards. Perhaps we may conclude that some Latin versions of Manichaean writings date from the same time as their Coptic counterparts. ${ }^{14}$

\section{Augustine's concubine?, ca. 373-385, Roman Africa-Rome-Milan (sources: conf. 4,2; 6,25)}

To a certain extent, the unnamed mother of the unnamed African bishop may have had her counterpart in Augustine's concubine. In this case, too, we only know she was from Roman Africa, but we do not know her name. Even her adherence to Mani's religion is not an established fact. Yet she may be

Boston-Köln 1995, $\left.{ }^{*}\right)$ : '[The] second work of the catechumena[te that he] does is this: A person will give a child to the $[\mathrm{ch}] /$ urch for the (sake of) righteousness, or his relative [or member] / of the household; or he can rescue someone beset by troub[le; or] / buy a slave, and give him for righteousness. Accordingly, every [go]/od he might do, namely this one whom he gave as a gift [for righ]teousness; that catechumen [...] / will share in with them'.

11 P. Kellis Copt. 19 in I. Gardner, A. Alcock and W.-P. Funk, Coptic Documentary Texts from Kellis, I, Oxford 1999, 77; cf. e.g. E. Iricinschi, 'Tam pretiosi codices vestri. Hebrew Sciptures and Persian Books in Augustine's Anti-Manichaean Writings', in: Ph. Townsend \& M. Vidas (eds.), Revelation, Literature, and Community in Late Antiquity, Tübingen 2011, 155.

12 E.g. J. van Oort, 'Young Augustine's Knowledge of Manichaeism. An Analysis of the Confessiones and Some Other Relevant Texts', vc 62 (2008) 441-466; idem, 'Manichaean Christians in Augustine's Life and Work', CHRC 90 (2010) 505-546; idem, 'Augustine and the Books of the Manichaeans', in: M. Vessey (ed.), A Companion to Augustine, Malden \& Oxford 2012, 188-199.

13 Conf. 5,11: 'et [legerat... libros] suae sectae si qua volumina latine atque conposite conscripta erant'.

14 As a rule the Manichaean Coptica such as the Kephalaia, the Manichaean Psalmbook and the Homilies are dated to c. 350. The same goes for the Greek Codex Manichaicus Coloniensis. 
discussed here, because she adhered to the (for a long time ardently proselytizing) Manichaean Augustine. Perhaps full consideration of this fact may yield some unexpected evidence.

What can we say about her? Our key sources are restricted to two passages in Augustine's Confessions. In conf. 4,2, he tells us: 'In those years I had someone, not in what is called lawful marriage. I had found her in my wandering desire and lack of prudence. Nevertheless, she was the only one, and I was faithful to her in whom I found out truly by my own experience what difference there is between the restraints of the marriage bonds, contracted for the sake of issue, and the compact of a lustful love, where children are born against one's will, although, once they are born, they compel love.'.15

First it should be noted that Augustine begins the passage with 'in illis annis', which is an explicit reference to his years as a Manichaean. ${ }^{16}$ All he tells here should be heard in this context. Speculation that he may have met the woman when he was seventeen, during the year of indolence that he spent in his hometown Thagaste, ${ }^{17}$ is a figment of imagination. ${ }^{18}$ According to any logical sequence of Augustine's account he must have met the young woman in Carthage, the city where he studied from the end of 370 or early 371 onwards and where, according to the beginning of conf. 3 , he first lived in some state of unbridled sex ${ }^{19}$ before his liaison. In all likelihood, the woman involved soon became the mother of Adeodatus, i.e., in late 372 or early $373 \cdot{ }^{20}$ In the latter

15 Conf. 4,2: 'In illis annis unam habebam, non eo quod legitimum vocatur coniugio cognitam, sed quam indagaverat vagus ardor inops prudentiae, sed unam tamen, ei quoque servans tori fidem; in qua sane experirer exemplo meo, quid distaret inter coniugalis placiti modum, quod foederatum esset generandi gratia, et pactum libidinosi amoris, ubi proles etiam contra votum nascitur, quamvis iam nata cogat se diligi'.

16 Cf. the beginning of conf. 4,1 (and thus of the whole book 4): 'Per idem tempus annorum novem, ab undevicensimo anno aetatis meae usque ad duodetricensimum, seducebamur et seducebamus ...' and the phrase 'in illis annis' at the beginning of 4,2 , which is repeated in our passage.

17 On this period conf. 2,5-6.

18 O'Donnell, Confessions, II, 207, in a passage full of other mistakes on the data of Adeodatus.

19 Conf. 3,1: 'Veni Carthaginem, et circumstrepebat me undique sartago flagitiosorum amorum'. Etc.

20 In conf. 9,14 A. remarks that, at the moment of his inscription as candidate for baptism at the beginning of Lent in 387 , Adeodatus was 'almost fifteen years' (annorum erat ferme quindecim). Note that ferme here is 'almost' and not 'about' as all English translations known to me will have it. One may ask if it is reasonanble to conceive a father who does not know the exact age of his beloved only son at such an incisive moment? Moreover, 'almost' fully corresponds with A.'s further remarks in conf. 9,14 that Adeodatus at the time of his interlocutions in De magistro was 'in his sixteenth year' (cum esset in annis 
year, Augustine became a Manichaean auditor, a rank which allowed him to have a concubine, with the proviso that no children would be born out of their sexual relationship. In view of the fact that contraceptive measures were well known in Manichaean circles, ${ }^{21}$ it is telling that this son remained the only one. But, was this carried out without the concubine's consent, or may we infer that she adhered to the Manichaean principles as well?

Based on the common English translations of the phrase 'ubi proles etiam contra votum nascitur, quamvis iam nata cogat se diligi' at the end of conf. 4,2 as 'where children are born against their parents' will, although, being born, they compel love,'22 one might conclude that both parents adhered to the Manichaean contraceptive measures and, thus, that Augustine's concubine had become a Manichaean as well. This reasoning, however, does not have a basis in the Latin text: it is only said that 'children are born against one's will'. Another assumption, namely that 'votum' in the same passage refers to the Manichaean 'seal of the bosom, ${ }^{23}$ does not provide much help: in mor. 2,65 Augustine comments on the contents of the signaculum sinus, which in the case of the auditores consisted of the admonishment 'to us to observe, as much as we can, the time at which a woman is ready for conception after her menstrual period and to abstain from intercourse at that time so that the soul does not become entangled in flesh.24 Unfortunately (though understandably for Augustine's age) there is no mention of any active role of the female partner. In c. Faust. 20,23, we read in a passage closely parallel to the phrase quoted above

sedecim), i.e. 15 . The dialogue mag. dates from the time of A.'s return to Thagaste, most probably 388 .

See e.g. mor. 2,65 (CSEL 90, 146-147); c. Faust. 22,30 (CSEL 25, 656); haer. 46,13 (CCL 46, 317); cf. Coyle, 'Augustine and Manichaeism on Contraception', in: idem, Manichaeism and Its Legacy (n. 1), 283-295.

See e.g. the (perhaps most vulgated) translation of E.B. Pusey in $N P N F$, also often republished in Everyman's Library; cf. e.g. H. Chadwick, Saint Augustine, Confessions (Oxford World's Classics), Oxford 1991, 53; M. Boulding, The Confessions (The Works of Saint Augustine. A Translation for the 21st Century), New York 1997, 93. But see also e.g. $B A$ 13, 411: 'malgré le vœu contraire des parents', as P. de Labriolle already translated in the Collection Budé (Paris 1925', 67: 'mais contre le vœu de leurs parents').

23 C. Starnes, Augustine's Conversion. A Guide to the Argument of Confessions I-IX, Ontario 1990, 91 and $107 \mathrm{n}$. 10. It should be doubted, however, that votum in the just quoted text explicitly refers to the Manichaean signaculum: as far as I can see, nowhere else when speaking of the Manichaean tria signacula Augustine terms them to be vota.

24 Mor. 2,65: 'Nonne uos estis qui nos soletis monere, ut quantum fieri posset, obseruaremus tempus quo ad conceptum mulier post genitalium uiscerum purgationem apta esset eoque tempore a concubitu temperaremus, ne carni anima implicaretur?' 
from conf. 4,2: 'your auditores have wives, and in spite of themselves (quamuis inuiti) receive children'. It might be that some notion of the signaculum sinus is at the background here, but nowhere in the context is this explicitly stated. The usual prima facie understanding of contra votum as 'against one's will' seems to be most plausible one.

All this does not imply, however, that the role of Augustine's concubine should remain completely in the dark. From his book on the Manichaean way of life we get some telling glimpses of Manichaean women. Not only an electa, but also female auditors and, what is more important, a woman of an auditor play some part in it. Defaming the ethics of his former co-believers, Augustine relates rumours that 'some (Elect) were proven to have seduced other men's wives. ${ }^{25} \mathrm{He}$ also tells that a woman (mulier) of the sect complained to him and his friends that she, in an assembly where also other women (feminae) were present, after the Elect had entered and one of them had put out the light, 'was seized in the dark in the embrace of one of them and would have been forcibly violated if she had not escaped by shouting. ${ }^{26}$ The story proves that, in any case, one (married or otherwise conjugated) woman (mulier) took part in that assembly 'on the night when you celebrated the feast of vigils'. ${ }^{27}$ Perhaps she was the partner of some auditor. In another story told by Augustine it is explicitly stated that 'a man (obviously an electus) had violently attacked the

25 Mor. 2,68: 'Nonnulli alienas feminas seduxisse approbati sunt, ita ut hinc plane dubitare non possim.- - A. adds to this: 'Sed sit et haec magis fama quam uerum', a sentence which Baker-Brian, 'Women' (n. 2), reads out of context and misinterprets, as if fama is A.'s main and real basis for his anti-Manichaean polemic in mor. 2. A. tells in $\S 68$, that 'during [the] nine full years (nouem annis totos) that he was a Manichaean auditor, he was told much gossip on the Elect's behaviour: many of them did drink wine and eat flesh, and many visited the public baths. He explicitly states: 'Sed haec audiabamus'. He goes on to speak of the rumours that some Elect were proved (approbati) to have seduced other men's wives. He then adds: 'But, also this may be a rumour (fama) rather than a fact (uerum)'. Next, he rather extensively speaks of an Elect's misbehaviour which he himself saw in Carthage. Baker-Brian makes this specific and carefully formulated concession of A. ('also this may be rather fama than uerum') into a (near-)general rule ('Augustine openly declares that much of what he has to say about Manichaean morals (specifically the conduct of the Elect), "is more rumour ( fama) than truth", 'Women', 503) and he deduces all too much from the quote in order to prove that, in essence, A. relied on rumour in his rhetorical denunciation of the Manichaeans. The same generalisation in Baker-Brian, 'Between Testimony and Rumour' (n. 2), where (47) he even omits the contextualizing 'et haec' from the quote.

26 Mor. 2,70: 'in tenebris appetita esset amplexu et coacta in flagitium, nisi subsidio clamoris euasisset'.

27 Ibidem: 'ea nocte qua festae apud uos uigiliae celebrantur'. 
wife of a certain auditor' ${ }^{28}$ Evidently women of auditores did play a role in the Manichaean ecclesia. ${ }^{29}$ It is only reasonable to assume that they adhered to the Manichaean principles required. In the case of Augustine's concubine we may suppose that, at least for some time, she gave her consent to the Manichaean principles of her partner as well.

The second text in which Augustine explicitly mentions his concubine is conf. 6,25: 'Meanwhile my sins multiplied, and the woman with whom I habitually slept was ripped from my side because she was regarded as an impediment to my marriage. My heart, deeply attached to her, was cut and wounded and left a trail of blood. She had returned to Africa, vowing to you that she would never be intimate with another man. The son I had fathered by her was left with me.'30 The fact that the woman vowed to God (vovens tibi) is sometimes taken as a proof of her being a (Catholic) Christian. ${ }^{31}$ One may doubt ${ }^{32}$ this reasoning, however, or at the most concur with it only as far as the described episode is in view. Her decision to celibacy was taken at the time when her partner was an ex-Manichaean and on the verge of becoming a Nicene Catholic Christian subscribing to strict celibacy as well.

\section{Cypriana, Wife of Manichaean Romanianus?, ca. 375-408, Roman Africa (source: ep. 259)}

Another example of a wife of a Manichaean auditor who, in all probability, was herself a Manichaean as well, could be a certain Cypriana. She is mentioned

28 Mor. 2,71: ' $\ldots$. ab eo uiolenter attentatam cuiusdam auditoris uxorem'.

29 The term ecclesia is found at the end of mor. 2,68 and also in 2,72.

30 Conf. 6,25: 'Interea mea peccata multiplicabantur, et avulsa a latere meo, tamquam inpedimento coniugii, cum qua cubare solitus eram, cor, ubi adhaerebat, concisum et vulneratum mihi erat et trahebat sanguinem, et illa in Africam redierat, vovens tibi alium se virum nescituram, relicto apud me naturali ex illa filio meo'.

31 See e.g. G. Madec, 'Adeodatus', $A L 1$ (1986) 88: 'On peut conclure de la mention de ce vœu qu'elle était chrétienne (de longue date? avant de connaître A.?) et qu'elle se fit religieuse'. A similar view is expressed by, for instance, P. Brown, Augustine of Hippo. A Biography, Berkeley and Los Angeles 2000 (1967), 80: 'Thus, this nameless woman will return to Africa, "vowing never to know a man again". In all probability she had been a good Catholic throughout her life with Augustine; and, by this vow, she intended either to become eligible for baptism, or to be re-admitted to the Eucharist'. Cf. Brown, ibidem, 51-52: "Throughout her partner's Manichaean enthusiasms, Augustine's concubine may have remained a Catholic catechumen"'.

32 Cf. J.D. BeDuhn, Augustine's Manichaean Dilemma, I: Conversion and Apostasy, 373-388 C.E., Philadelphia 2010, ${ }^{*-*}$. 
in a letter of Augustine written in 408 to a certain Cornelius. ${ }^{33}$ Following a compelling study of Aimé Gabillon, ${ }^{34}$ scholars generally identify this Cornelius as Romanianus, the erstwhile benefactor of Augustine and, through him, for many years an auditor with the Manichaeans. ${ }^{35}$ Later on he turns out to be a Catholic Christian, ${ }^{36}$ perhaps under Augustine's influence as well. Letter 259 reveals that, originally, young Cornelius was a man of impure manners; later he joined Augustine in his errors and in those days he was chaste; as a Catholic catechumen, however, he slid back into his old unchaste habits and, although he received baptism in danger of death, afterwards slid back again. ${ }^{37}$ Recently his wife Cypriana died and, although surrounded by a host of women and a day by day multiplying number of concubines, ${ }^{38}$ he dares to solicit Augustine for a letter of consolation. Augustine refuses and throughout the letter he stresses the chasteness of Romanianus' wife (uxor; coniunx). ${ }^{39}$ One may suppose that this strict castitas of spouse and mother ${ }^{40}$ Cypriana, like in the case of Augustine's concubine, has direct links with her formerly being the wife of a Manichaean auditor.

33 Cf. J. Divjak, 'Epistulae', $A L 2$ (1996-2002) 1007-1008.

34 A. Gabillon, 'Romanianus, alias Cornelius. Du nouveau sur le bienfaiteur et l'ami de saint Augustin', REA 24 (1978) 58-70.

35 See e.g. acad. 1,3; cf. PAC s.v. 'Romanianvs'.

36 A. Fitzgerald, 'Romanianus', AthA, 730 states that 'Romanianus became a Christian in 396'; cf. $P A C$ s.v., where (996) reference is made to A.'s ep. 31 (A. to Paulinus of Nola) in which A. speaks of 'ce qu'il porte en lui de bien et ce qui cloche du fait d'un restant de faiblesse' $(31,7)$. This pars infirmitatis may refer to 'frater' Romanianus' impure sexual manners. Divjak, 'Epistulae', $A L 393$ and 1028 dates the letter to 395/396.

37 Ep. 259,3: 'Qui cum esses, non dicam catechumenus, sed in errore nobiscum perniciosissimo constitutus iuvenis, iunioribus nobis, ab hoc te vitio temperantissima voluntate correxeras, quo non post longum tempus sordidius revolutus, deinde in extremo vitae periculo baptizatus....

$38 \quad$ Ep. 259,3: 'Plebs mulierum excubat lateribus tuis, crescit in dies pellicum numerus ...'; cf. 4: 'amorem concubinarum tuarum'.

39 Ep. 259,1: 'Et illa quidem anima in societatem recepta fidelium atque castarum'; 3: 'laudes defunctae castae coniugis'; 4: 'laudem pudicissimae coniugis tuae'; 'quanto magis te casta non vult ad poenas venire moechorum'.

40 She was the mother of Romanianus' son Licentius. Perhaps he had as a brother Lucinianus (cf. PAC s.v. Lvcinianvs, 651). In all likelihood, these young men participating in the Cassiciacum dialogues were born before $373 / 4$, i.e. before the time Romanianus became an adherent of Mani. 


\section{Eusebia, Manichaean electa and Margarita, Manichaean electa (?), 421, Carthage (sources: haer. 46; Possidius, uita Aug. 16)}

Quite another matter is at stake with two other women. In haer. 46,9 Augustine tells his addressee Quodvultdeus the following story which, because of its important context, I first present in full. It runs in the translation of L.G. Müller: ${ }^{41}$

In this circumstance [i.e., in light of the so-called 'Seduction of the Archons' myth of the Manichaeans briefly discussed in § 8], or rather because of some demand of their detestable superstition, their Elect are forced to consume a sort of eucharist sprinkled with human seed in order that the divine substance may be freed even from that, just as it is from other foods of which they partake. However, they deny that they do this, claiming that some others do it, using the name of the Manichaeans. But they were exposed in the Church at Carthage, as you know, for you were a deacon there at the time when, under the prosecution of Ursus the tribune, who was then prefect of the palace, some of them were brought to trial. At this time a girl by the name of Margaret gave evidence of their obscene practices and claimed, though she was not yet twelve years old, that she had been violated in the performance of this criminal rite. Then with difficulty he compelled Eusebia, some kind of Manichaean nun, to admit that she had undergone the same treatment in this regard, though at first, she maintained that she was a virgin and insisted on being examined by a midwife. When she was examined and when her true condition was discovered, she likewise gave information on that whole loathsome business at which flour is sprinkled beneath a couple in sexual intercourse to receive and commingle with their seed. This she had not heard when Margaret gave her testimony, for she had not been present. ${ }^{42}$

L.G. Müller, The De Haeresibus of St. Augustine. A Translation with an Introduction and Commentary (The Catholic University of America Patristic Studies, Vol. 9o), Washington, D.C. 1956, 89-91. Cf. the translation by R.J. Teske in Arianism and Other Heresies (The Works of Saint Augustine. A Translation for the 21st Century, Part I, Vol. 18), New York 1995, 43-44.

42 Haer. 46, 9 (Latin text according to the edition by R. Vander Plaetse and C. Beukers, $C C L$ 46, 314-315): 'Qua occasione, uel potius exsecrabilis superstitionis quadam necessitate, coguntur Electi eorum uelut eucharistiam conspersam cum semine humano sumere ut etiam inde, sicut de aliis cibis quos accipiunt, substantia illa diuina purgetur. Sed hoc se facere negant, et alios nescio quos sub nomine Manichaeorum facere affirmant. Detecti sunt tamen in ecclesia, sicut scis, apud Carthaginem, iam te ibi diacono constituto, quando instante Vrso tribuno, qui tunc domui regiae praefuit, aliqui adducti sunt. Vbi puella 
Briefly stated, the story tells that-on the initiative of the (Catholic) tribune Ursus $^{43}$ - a number of Manichaeans have been arrested and brought before the ecclesiastical authorities. ${ }^{44}$ Possidius says that all of them were Elect. ${ }^{45}$ During their interrogation by the ecclesiastical authorities-among whom Augustine was present ${ }^{46}$ - a certain girl named Margarita gave evidence of their obscene practices and claimed that she had been violated (uitiatam) in the performance of some criminal rite. Augustine relates that the rite consisted of some sort of 'semen eucharist': Elect consumed 'a sort of eucharist sprinkled with human seed so that the divine substance may be freed'. In order to prepare this eucharistia, there was a sexual act between men and women while some flour was spread 'under a couple in sexual intercourse to receive and commingle with their seed'. A certain woman Eusebia was forced to admit the same act. To Augustine, all this is in actual fact no surprise, because-as he states in the following paragraph - the Manichaean books describe 'these dreadful things relating to the transformation of males into females, and of females into males to attract and to loosen through concupiscence the princes of darkness of both sexes so that the divine substance which is imprisoned in them may be set free and escape. ${ }^{47}$ In other words, their 'obscene practices' are inspired by the well-known scene of the 'Seduction of the Archons' in the Manichaean myth.

illa nomine Margarita istam nefariam turpitudinem prodidit, quae cum esset annorum nondum duodecim, propter hoc scelestum mysterium se dicebat esse uitiatam. Tunc Eusebiam quandam manichaeam quasi sanctimonialem, idipsum propter hoc ipsum passam, uix compulit confiteri, cum primo illa se asseruisset integram, atque ab obstetrice inspici postulasset. Quae inspecta et quid esset inuenta, totum illud turpissimum scelus, ubi ad excipiendum et commiscendum concumbentium semen farina substernitur, quod Margarita indicante absens non audierat similiter indicauit. [...]'

Cf. Vrsvs 3, PAC, 1236.

44 Cf. Possidius, Vita, 16.

45 Ibidem: '... ad quosdam Manichaeorum, quos electos vel electas dicunt...'; ‘... feminarum illarum velut electarum.....

46 Ibid.: 'Inter quos [sc. episcopos] etiam sanctae memoriae Augustinus fuit....-BakerBrian, 'Women' (n. 2), 515 argues that 'the account in haer. says nothing of Augustine's involvement in the proceedings'. However, I would advance 'detecti sunt tamen in ecclesia, sicut scis ('as you [too] know'), apud Carthaginem' etc., as suggesting exactly such a personal presence.

47 Haer. 46,10: '... in quibus libris illa portenta ad illiciendos et per concupiscentiam dissoluendos utriusque sexus principes tenebrarum ut liberata fugiat ab eis quae captiua tenebatur in eis diuina substantia, de masculorum in feminas et feminarum in masculos transfiguratione conscripta sunt.... 
What exactly does the story tell about the Manichaean women involved? First there is Margarita. Curiously, she is said to be a young girl (puella) of 'not yet twelve years old' (annorum nondum duodecim) and, at the same time-if we may trust the explicit testimony of Possidius ${ }^{48}$ —an electa. This would then mean that even a youngster of less than twelve years could belong to the class of Elect. Should we stick to the literal statement of Possidius, or lay stress on the fact that Augustine does not explicitly say so ${ }^{49}$ Evidently the young girl Margarita did not know of all Manichaean rites performed, for she claimed that she had been 'violated' (vitiata). In all likelihood she was some oblate entrusted to electae in order to be prepared for her own status as electa. ${ }^{50}$

The second woman is Eusebia. She is termed, by Augustine, as being 'some kind of Manichaean nun' (quandam manichaeam quasi sanctimonialem). Quasi ('as it were') seems to express some irony on the part of Augustine, for, in actual fact, after being examined by a midwife, she turned out to be no virgin. Moreover, she appears to have been well informed of the Manichaean rites and approved of them. For Augustine the whole event is ultimate proof of a most horrible deed ${ }^{51}$ he had for many years suspected to be Manichaean practice. ${ }^{52}$

48 See $n .45$ above.

$49 P A C, 698$ s.v. Margarita 2, does not state this either, although the brief entry has a reference to Possidius, Vita 16.

$50 \quad$ Cf. F. Decret, L'Afrique manichéenne (IV $V_{-} V^{e}$ siècles), I, Paris 1978, 370: 'Il est probable qu'elle avait été confiée à des Élues qui avaient charge de préparer des jeunes filles à leur future profession de « sanctimonales »'.

$5^{1}$ Cf. haer. 46,9: 'totum illud turpissimum scelus'.

$5^{2}$ See e.g. mor. 2,66; c. Fort. 3; nat. b. 47.- It should be noted that A. only speaks of the (in these texts only supposed and insinuated resp.) Manichaean consumption of semen, but never alleges that they ate 'human excrement', as stated by Baker-Brian, 'Women' (n. 2), 506, with reference to mor. 2,41. In mor. 2,41 A. ridicules the Manichaeans' attentiveness to the colour of food and sarcastically remarks that 'in colour alone the excrement of an infant surpasses lentils' ('Colore solo lenticulam fimus uincit infantis'). This does not mean any actual coprophagia, however, and the reference (506, n. 33) to compare $C M C$ 81, 2-13 is meaningless. Faulty as well is the inference on the basis of mor. 2,66 that A. seriously meant that the Manichaeans consumed the seed of animals ('Women', 506, 513; 'Between Testimony and Rumour', 47-48: ' . . the Elect open themselves to the slanderous inference that, in secret-away from the hearers—-they consume the seed of animals'): in mor. 2,66 A. only poses a rhetorical (though very insinuating) question: 'Cur enim de tritico et de faba et de lenticula alliisque seminibus, cum his uescimini, liberare uos uelle animam creditur, de animalium seminibus non credatur?'. 


\section{Conclusion}

At the end of this overview, we may conclude that Manichaean women played a considerable role in Augustine's life and works. Recent discoveries such as the Cologne Mani Codex and the excavations of Kellis in Roman Egypt place their data in a wider perspective. It turns out that, at quite different stages of his life, Augustine experienced the presence of Manichaean women. From his time and world we have neither archaeological remains (such as in case of the epitaph from Salona in Dalmatia on 'Bassa a virgin [= electa] from Lydia, a Manichaean' $)^{53}$ nor testimony of a discussion with a Manichaean female intellectual (such as in the case of Augustine's contemporary Julia of Gaza). ${ }^{54 *}$ Yet it may be supposed that also in Roman Africa (and contemporary Italy or nearby Spain, for that matter), Manichaean women-apart from being associated with auditores - functioned in missionary activities and, for instance, also in official church functions, such as scribes. ${ }^{55}$ In all likelihood it was already at the end of the third century, when Manichaeism had just entered the African continent, that bishop Theonas of Alexandria warned especially against Manichaean women, ${ }^{56}$ and from the same time we have Diocletian's edict issued after having received a report from Amnius Anicius Julianus, the proconsul of Africa. ${ }^{57}$

All this gives evidence of the presence of Manichaeism in Augustine's life and works, and of the role that Manichaean women played in it. However, to conclude from the texts discussed above that Augustine was 'very likely taking advantage of the long-standing assumption that "the very visibility of women in such accounts [cf. mor. 2,41 and 66; haer. 46] is used as evidence of a crime" ${ }^{58}$ seems to stretch the textual evidence. Indeed, women are markedly present in certain stories and invectives, but on close reading of the texts the

53 See most recently Scopello, 'Bassa la Lydienne' (n. 1).

54 See e.g. Scopello, 'Julie, Manichéenne d'Antioche (d'après la Vie de Pophyre de Marc le Diacre, ch. 85-91) (n. 1); cf. e.g. R. Lim, Public Disputation, Power, and Social Order in Late Antiquity, Berkeley 1995, 16-30.

55 Cf. P. Kellis Copt. 19 (cf. above, n. 10).

56 C.H. Roberts, '469. Epistle against the Manichees', Catalogue of the Greek and Latin Papyri in the John Rylands Library Manchester, III, Manchester 1938, 38-46. Here also more on the likely date and provenance. The Greek text also in A. Adam, Texte zum Manichäismus, Berlin 1969, 52-54; cf. S.N.C. Lieu, Manichaeism in the Later Roman Empire and Medieval China, Tübingen 1992, 128, with Greek quotes.

57 See e.g. Lieu, Manichaeism, 121-125.

$5^{8}$ Baker-Brian, 'Women' (n. 2), 501, with a quote from M.Y. MacDonald, Early Christian Women and Pagan Opinion, Cambridge 1996, 59. Cf. ibidem, $5^{20}$. 
same appears to be the case for Manichaean men (see the male Elect in the discussed passages of mor. and haer.!).

Future studies of the place and role of the women married to Manichaean auditores may make our picture of Manichaean women in Augustine's time and world more profound. The same may a fortiori go for further analyses of the place and role of the Manichaean female auditors themselves: their quantity and significance may be comparable to the successful activity of women in early Christianity which, in its initial stages, was an underground, counter-cultural sect as well. ${ }^{59}$ Future studies are also required on the place and role of Manichaean women in the production of manuscripts and, for instance, church music. What exactly can we say of the Manichaean books (and their illustrations!) and the female participation in their production in Roman Africa? ${ }^{60}$ What of women's role in Manichaean church music (which impressed Augustine so much) ${ }^{61}$ Whatever the answers to all these intriguing questions, from the data traced and discussed above it has become evident that the presence of Manichaean women in Augustine's life and works was considerable.

59 Among the many studies on the subject, see e.g. R. Stark, The Rise of Christianity. A Sociologist Reconsiders History, Princeton, NJ 1996, esp. 95-128.

6o Unfortunately, the recent book of Kim Haines-Eitzen, The Gendered Palimpsest. Women, Writing, and Representation in Early Christianity, Oxford 2013 does not deal with Manichaean women, but it may provide clues for further study.

61 Cf. conf. 3,14; 10,49. 